\title{
Development of a selective biopharmaceutical from Herpes simplex virus type 1 glycoproteins $E$ and I for blocking antibody mediated neutralization of oncolytic viruses
}

SEPTIMIU BUCURESCU

»Rhoen Klinikum AG« Hospital 97616 Bad Neustadt ad Saale, Germany

Accepted October 22, 2010
Future cancer therapies will be molecular cures. They will correct, block or destroy cancer cells by targeting molecular changes that lead to carcinogenesis. Destroying cancer cells can be done using oncolytic viruses. By blocking antibody mediated neutralization of oncolytic viruses, Herpes simplex virus type 1 glycoproteins E and I could be used in the adjuvant treatment of cancer for improving the chances of oncolytic viruses to kill cancer cells in vivo.

Keywords: cancer therapies, Herpes simplex virus type 1 glycoproteins $\mathrm{E}$ and I, antibody mediated neutralization of oncolytic viruses

\section{INTRODUCTION}

According to the World Health Organization, cancer is the second cause of death worldwide (12\% of all causes) after cardiovascular diseases. In 2000 there were 10 million new cases of cancer worldwide and by 2020 there could be a $50 \%$ increase, to 15 million (1).

\section{Current cancer therapies}

Current cancer therapies are either local or systemic treatments. Local treatments include surgery and radiation therapy. Systemic treatments include chemotherapy, hormone therapy and biological therapy. There are two problems with these therapies: they are oncostatic and have poor selectivity (2).

Oncostatic therapies suppress cancer cell growth and proliferation (3). Due to the fact that current therapies are oncostatic, survival rates for most cancers are generally unsatisfactory. By the end of the $20^{\text {th }}$ century, 5-year relative survival rates for the 4 most common cancer sites (prostate, breast, colorectal and lung) were $98 \%$ for prostate cancer

Correspondence; e-mail: s_bucurescu@yahoo.com 
S. Bucurescu: Development of a selective biopharmaceutical from Herpes simplex virus type 1 glycoproteins E and I for blocking antibody mediated neutralization of oncolytic viruses, Acta Pharm. 60 (2010) 407-413.

in males, $15 \%$ for lung cancer in both sexes, $62 \%$ for colorectal cancer in both sexes and $86 \%$ for breast cancer in females (4).

Due to the fact that current cancer therapies have poor selectivity, side effects are common. Some side effects are minor, resulting in patient discomfort, others, however, are major (e.g., chemotherapy induced pancytopenia) and require treatment (5).

\section{Future cancer therapies}

Future therapies will be most likely molecular cures. They will correct, block or destroy cancer cells by targeting molecular changes that lead to carcinogenesis. Correction of cancer cells could be achieved by fixing DNA mutations using genetic engineering. Blocking of cancer cells could be achieved by interfering with transcription and translation. Destroying cancer cells can be done using oncolytic viruses (6).

The oncolytic properties of some viruses were detected 100 years ago. The first published report to establish a link between a virus infection and cancer regression appeared in the early 1900's. In 1912, it was reported in Europe, that a woman's cervical cancer improved subsequent treatment to prevent rabies. The woman was bitten by a dog and was injected with a vaccine made of attenuated rabies virus (7). The first report of positive results using wild type viruses to treat human cancer were published in the 1950's and 1960's, e.g. adenovirus (AdenoV) in 1956 and Newcastle Disease Virus (NDV) in 1964. Clinical trials for wild type and mutant oncolytic viruses began in the 1990's (8). Several oncolytic viruses have now advanced to late phase clinical trials, e.g., AdenoV H101 phase III clinical trial for head and neck cancers and NDV MTH-68H phase II clinical trial for metastatic solid cancers (9). The first oncolytic virus, a genetically modified AdenoV H101, received regulatory approval in 2005 and was put on the market in China (10).

Oncolytic viruses have two major advantages over current therapies: they are oncolytic and have high selectivity (11). This is due to the fact that they take advantage of the intracellular aberrations in signalling pathways that are associated with carcinogenesis (12). There is one major problem with both wild type and mutant viruses: the high efficacy in vitro cannot be replicated in vivo. The patient's antiviral immune response due to preformed circulating antibodies and T-cell memory from prior exposure to the virus is blocking virus replication in vivo (13).

In order to be efficacious, in vivo oncolytic viruses should be able to avoid the immune system, reach all cancer cells, kill all cancer cells and leave a long lasting host immune response against cancer cells. As we can easily imagine, an ideal virus must inactivate antibodies (and complement), attach, internalize, replicate and kill cancer cells, release progenies that will kill all cancer cells, stimulate the host immune response to cancer cells, not be able to replicate inside normal cells and be able to be inactivated by drugs (6).

Inactivation of antiviral antibodies can be done by temporary immunosuppression. There are several classes of immunosuppressive drugs currently available on the market (14). However, since they are not selective, they cannot be associated with oncolytic viruses. By inhibiting also cellular immunity, they would prevent the virus from leaving a long-lasting immune response against cancer relapse. Inactivation of humoral immunity only could be done by developing biopharmaceuticals that selectively block humoral immunity without affecting cellular immunity. 
S. Bucurescu: Development of a selective biopharmaceutical from Herpes simplex virus type 1 glycoproteins E and I for blocking antibody mediated neutralization of oncolytic viruses, Acta Pharm. 60 (2010) 407-413.

\section{BLOCKING IMMUNITY BY HERPES SIMPLEX VIRUS TYPE 1 GLYCOPROTEINS E AND I}

\section{Structure and function of Herpes simplex virus type 1 glycoproteins $E$ and I}

Herpes simplex virus type 1 (HSV-1) are one of the most studied viruses. The structure and function of glycoproteins $\mathrm{E}(\mathrm{gE})$ and $\mathrm{I}(\mathrm{gI})$ are well known.

Glycoprotein E is a 550 amino acid type I transmembrane glycoprotein that has two potential N-linked glycosylation sites and contains nine cysteines in the extracellular domain, one cysteine in the cleaved signal sequence and another in the transmembrane domain. The gene that codes gE (Us8) was identified in 1985 (15). The amino acid region required for binding antibody (235-380) and for complex formation (235-264) was identified in 1995 (16).

Glycoprotein I is a 390 amino acid type I transmembrane glycoprotein that contains three potential $\mathrm{N}$-linked glycosylation sites and a cluster of four cysteine residues in the extracellular domain. The gene that codes gI (Us7) was identified in 1985 (15). The amino acid region required for complex formation (43-192) was identified in 1997 (16).

Glycoproteins E and I are immune evasion proteins that protect HSV from antibody-mediated immune attack. They form a hetero-oligomer complex that binds the fragment crystallizable (Fc) domain of immunoglobulin G (IgG) in both IgG aggregates and monomers. While the anti-HSV IgG binds to its target antigen by its fragment antigen binding (Fab) end, the gE/gI complex binds the IgG Fc end. The process, demonstrated by in vitro studies, is called bipolar bridging. Antibody bipolar bridging also inhibits complement activation by the IgG Fc domain (16).

Studies have been done to define the role of $\mathrm{gE}$ and $\mathrm{gI}$ in immune evasion in vivo. A mutant HSV was constructed (NS-gE $E_{339}$ ) that does not bind the Fc domain of IgG, thus being unable to inactivate IgG through bipolar bridging. Mice were passively immunized with human anti-HSV IgG and then infected with wild-type and mutant HSV. As expected, human anti-HSV IgG reduced disease severity and viral titers in mutant-infected but not in wild-type infected mice. These experiments have shown that the $\mathrm{gE} / \mathrm{gI}$ complex provides significant protection against antibody mediated immunity in vivo (16).

\section{Therapeutic use of Herpes simplex virus type 1 glycoproteins E and I}

HSV-1 gE/gI complex selectively blocks human humoral immunity in vitro and in vivo without affecting cellular immunity. HSV-1 gE/gI complex is capable of inhibiting IgG, which composes $75 \%$ of the immunoglobulin pool, both in vitro and in vivo because it has Fc receptor ( $\mathrm{FCR}$ ) activity (17). HSV-1 usually produces a benign infection, primary infection resulting in gingivostomatitis and reactivation resulting in recurrent orolabial lesions (18).

The therapeutic efficacy of a future biopharmaceutical based on HSV-1 gE/gI is due to the fact that this complex is able to inhibit IgG both in vitro and in vivo. The therapeutic safety is due to the fact that HSV-1 infection is usually benign, thus a future biopharmaceutical based on HSV-1 gE/gI should be generating only minor side effects. Future work needs to be done before HSV-1 gE/gI can become a biopharmaceutical. 
S. Bucurescu: Development of a selective biopharmaceutical from Herpes simplex virus type 1 glycoproteins E and I for blocking antibody mediated neutralization of oncolytic viruses, Acta Pharm. 60 (2010) 407-413.

\section{HERPES SIMPLEX VIRUS TYPE 1 GLYCOPROTEINS E AND I FROM IDEA TO BIOPHARMACEUTICAL}

In order to move HSV-1 gE/gI from medical research into pharmaceutical research and development, future work must be done in regard to manufacturing, in vitro research, in vivo research, formulation and in vivo development.

\section{Manufacturing Herpes simplex virus type 1 glycoproteins E and I}

The purpose of these studies is to verify whether sufficient quantities of herpes simplex virus type 1 glycoproteins $\mathrm{E}$ and I can be manufactured using recombinant techniques. A possible research approach is described below.

Viral HSV-1 DNA that encodes gE and gI (HSV-1gE and HSV-1gI) must be cut from the HSV-1 genome using restriction enzymes. HSV-1gE and HSV-1gI must be purified by phenol extraction and ethanol precipitation (19). HSV-1gE and HSV-1gI must be included in an expression plasmid construction using, for instance, pUC18 as a vector (20). The plasmid must be transformed in Escherichia coli bacterial cells (19), where recombinant (r) HSV-1gE and HSV-1gI should be expressed (21). Purification of rHSV-1gE and rHSV-1gI can be done by cation-exchange chromatography and reversed-phase high performance liquid chromatography (22).

\section{In vitro research studies}

These studies will hopefully prove that rHSV-1gE and rHSV-1gI have the ability to inhibit humoral immunity in vitro. In vitro research studies can be done by using the rosettes method.

The rosettes method is an assay used to detect FcR activity for IgG aggregates. Sheep erythrocytes must be sensitized with subagglutinating concentrations of goat anti-sheep erythrocyte IgG. Sensitized sheep erythrocytes must be incubated for 2 hours at $37^{\circ} \mathrm{C}$ with Escherichia coli bacterial cells transformed with rHSV-1gE and rHSV-1gI in a ratio of 100:1. Erythrocyte rosette formation can be observed by light microscopy. A rosette is defined as a cell with more or at least four bound erythrocytes bordering its perimeter (23).

\section{In vivo research studies}

These studies will hopefully prove that rHSV-1gE and rHSV-1gI have the ability to inhibit humoral immunity in vivo. These studies also need to determine the optimum rHSV-1gE and rHSV-1gI dose at which antibody mediated neutralization of oncolytic viruses is inhibited in vivo in a murine model of cancer.

A murine model of cancer can be prepared by implanting human cancer cells into mice. Implantation needs to be orthotopic, at the correct anatomical site (e.g., human lung cancer cells need to be implanted in mice lungs). Orthotopic implantation mimics better the complexity of cancer behaviour in humans (24). Increasing doses of purified rHSV$-1 \mathrm{gE}$ and rHSV-1gI should be injected into the murine model of cancer before administering an oncolytic virus. Increased doses of oncolytic virus should be administered up 
S. Bucurescu: Development of a selective biopharmaceutical from Herpes simplex virus type 1 glycoproteins E and I for blocking antibody mediated neutralization of oncolytic viruses, Acta Pharm. 60 (2010) 407-413.

to the maximally tolerated dose (MTD), which is the highest dose that does not cause unacceptable side effects. MTD differs from oncolytic virus to another (25). A dose-response curve should be used to determine for each dose of administered oncolytic virus the optimum rHSV-1gE and rHSV-1gI dose (26).

\section{Formulation of $r H S V-1 g E$ and $r H S V-1 g I$}

Before pharmaceutical development can be started, a suitable drug formulation must be conceived. Since rHSV-1gE and rHSV-1gI is intended to be administered intravenously, it should be formulated as a sterile injection for intravenous administration. A drug concentration must be established (for example $1 \mathrm{mg} \mathrm{mL}^{-1}$ ). Several excipients must be added, such as an isotonic agent (for example $15 \mathrm{mg}$ glycerol), a conserving agent (for example $10 \mathrm{mg}$ benzyl alcohol), a pH stabilizer (for example sufficient natrium hydroxide for maintaining $\mathrm{pH} 4$ ), a protein aggregation inhibitor (for example $9 \mathrm{mg}$ zinc chloride) and a solvent (for example $9 \mathrm{mg}$ natrium chloride and water for injection add 1 $\mathrm{mL})(27)$.

In vivo development. - These studies will hopefully prove that rHSV-1gE/gI sterile injection for intravenous administration is efficacious and safe when administered to animals and humans. Non-clinical studies should be done according to the Good Laboratory Practice (GLP) standards (28). Clinical studies should be done according to the Good Clinical Practice (GCP) standards (29).

\section{CONCLUSIONS}

By blocking antibody mediated neutralization of oncolytic viruses, HSV-1 gE/gI could be used in the adjuvant treatment of cancer for improving the chances of oncolytic viruses to kill cancer cells in vivo. Although the structure and function of HSV-1 gE/gI are well known, future work needs to be done in order to obtain a biopharmaceutical based on recombinant glycoproteins. Manufacturing, therapeutic efficacy and therapeutic safety must be clarified through future research and development.

\section{REFERENCES}

1. B. Stewart and P. Kleihues, World Cancer Report, IARC Press, Lyon 2003.

2. National Cancer Institute, Methods for Treatment and Their Side Effects, http://www.nci.nih.gov/ cancertopics/wyntk/overview/page15, access date September 8, 2010.

3. T. W. Fischer, M. A. Zmijewski, B. Zbytek, T. W. Sweatman, R. M. Slominski, J. Wortsman and A. Slominski, Oncostatic effects of the indole melatonin and expression of its cytosolic and nuclear receptors in cultured human melanoma cell lines, Int. J. Oncol. 29 (2006) 665-672.

4. H. Brenner, Long-term survival rates of cancer patients achieved by the end of the $20^{\text {th }}$ century: a period analysis, Lancet 360 (2001) 1131-1135; DOI: 10.1054/bjoc.2001.1905.

5. J. L. Gajewski and R. E. Champlin, Blood Stem Cell and Marrow Transplantation, in Cancer Treatment (Ed. C. M. Haskell and J. S. Berek), W. B. Saunders, Philadelphia 2001, pp. 276-295. 
S. Bucurescu: Development of a selective biopharmaceutical from Herpes simplex virus type 1 glycoproteins E and I for blocking antibody mediated neutralization of oncolytic viruses, Acta Pharm. 60 (2010) 407-413.

6. S. Bucurescu, Introduction to Pharmaceutical Medicine, RG Fischer Verlag, Frankfurt am Main 2008, pp. 118-122.

7. N. dePace, Sulla scomparsa di un enorme cancro vegetante del collo dell'utero senza cura chirurgica, Ginecologia 9 (1912) 82-89.

8. E. Kelly and S. J. Russel, History of oncolytic viruses: genesis to genetic engineering, Mol. Ther. 15 (2007) 651-659; DOI: 10.1038/sj.mt.6300108.

9. T-C. Liu and D. Kirn, Gene therapy progress and prospects cancer: oncolytic viruses, Gene Ther. 15 (2008) 877-884; DOI: 10.1038/gt.2008.72.

10. K. Garber, China approves world's first oncolytic virus therapy for cancer treatment, J. Natl. Cancer I. 98 (2006) 298-300; DOI: 10.1093/jnci/djj111.

11. S. Meerani and Y. Yao, Oncolytic viruses in cancer therapy, Eur. J. Sci. Res. 40 (2010) 156-171.

12. Z. S. Guo, S. H. Thorne and D. L. Bartlett, Oncolytic virotherapy: molecular targets in tumor-selective replication and carrier cell-mediated delivery of oncolytic viruses, Biochim. Biophys. Acta 1785 (2008) 217-231; DOI: 10.1016/j.bbcam.2008.02.001.

13. S. Naik and S. J. Russel, Engineering oncolytic viruses to exploit tumor specific defects in innate immune signalling pathways, Expert Opin. Biol Th. 9 (2009) 1163-1176; DOI: 10.1517/ 14712590903170653.

14. R. Diasio and A. F. LoBuglio, Immunomodulators: Immunosuppressive Agents and Immunostimulants, in GoodmanEGilman's The Pharmacological Basis of Therapeutics (Ed. J. G. Hardman, A. Goodman Gilman and L. E. Limbird), McGraw-Hill, New York, 2006, pp. 1291-1308.

15. D. J. McGeoch, J. A. Dolan, S. Donald and F. J. Rixon, Sequence determination and genetic content of the short unique region in the genome of herpes simplex virus type 1, J. Mol. Biol. 181 (1985) 1-13; DOI: 10.1016/0022-2836(85)90320-1.

16. H. M. Friedman, Immune evasion by herpes simplex virus type 1, strategies for virus survival, Trans. Am. Clin. Climatol Assoc. 114 (2008) 103-112.

17. D. Westmoreland and J. F. Watkins, The IgG receptor induced by herpes simplex virus: studies using radioiodinated IgG, J. Gen. Virol. 24 (1974) 167-178; DOI: 10.1099/0022-1317-24-1-167.

18. J. P. G. Sissons, Herpes Viruses (Excluding Epstein-Barr Virus), in Oxford Textbook of Medicine (Eds. D. A. Warell, T. M. Cox, J. D. Firth and E. J. Benz), Oxford University Press, New York 2003, pp. 327-341.

19. J. Sambrook and D. Russel D, The Condensed Protocols from Molecular Cloning: a Laboratory Manual, CSHL Press, Cold Spring Harbor 2006.

20. J. Vieira and J. Messing, The pUC plasmids, an M13mp7-derived system for insertion mutagenesis and sequencing with synthetic universal primers, Gene 19 (1982) 259-268; DOI 10.1016/ 0378-1119(82)90015-4.

21. F. Baneyx, Recombinant protein expression in Escherichia coli, Curr. Opin. Biotechnol. 10 (1999) 411-421; DOI: 10.1016/50958-1669(99)00003-8.

22. J. Weiss, Handbook of Ion Chromatography, Wiley-VCH, Weinheim 2004, pp. 279-349.

23. J. F. Watkins, Adsorption of sensitized sheep erythrocytes to HeLa cells infected with herpes simplex virus, Nature 202 (1964) 1364-1365; DOI: 10.1038/2021364a0.

24. T. Van Dyke and T. Jacks, Cancer modeling in the modern era: progress and challenges, Cell 108 (2002) 135-144; DOI: 10.1016/S0092-8674(02)00621-9.

25. D. Cervantes-Garcia, R. Ortiz-Lopez, N. Mayek-Perez and A. Rojas-Martinez, Oncolytic virotherapy, Ann. Hepatol. 7 (2008) 34-45.

26. N. Ting, Dose Finding in Drug Development, Springer, New York 2006, pp. 304-310.

27. R. C. Rowe, P. J. Sheskey and M. E Quinn, Handbook of Pharmaceutical Excipients, Pharmaceutical Press, Chicago 2009, pp. 69-301. 
S. Bucurescu: Development of a selective biopharmaceutical from Herpes simplex virus type 1 glycoproteins E and I for blocking antibody mediated neutralization of oncolytic viruses, Acta Pharm. 60 (2010) 407-413.

28. International Conference on Harmonisation, Harmonised Tripartite Guideline, Timing of Non-clinical Safety Studies for the Conduct of Human Clinical Trials for Pharmaceuticals, ICH, Geneve 1998; http:/ / www.ema.europa.eu/ema/index.jsp?cure=pages/regulation/general/general_content_000430.jsp\&murl=menus $/$ regulations $/$ regulation.jsp\&mid=WC0b01ac058002992\&jsenabled $=$ true.

29. International Conference on Harmonisation Harmonised Tripartite Guideline, The Principles of Good Clinical Practice, ICH, Geneve 1996; http:/ /www.ich.org/LOB/media/MEDIA482.pdf.

\section{$S A \check{Z} E T A K$}

\section{Razvoj selektivnih biofarmaceutika iz glikoproteina E i I iz Herpes simplex virusa tipa 1 koji blokiraju neutralizaciju onkolitskih virusa posredovanu antitijelima}

SEPTIMIU BUCURESCU

Terapija karcinoma će u budućnosti biti na molekularnoj razini. Biti će moguće promijeniti, blokirati ili uništavati stanice ciljanim utjecanjem na molekularne promjene koje vode do karcinogeneze. Uništavanje stanica karcinoma moći će se ostvariti pomoću onkolitskih virusa. U pomoćnoj terapiji karcinoma moći će se koristiti glikoproteini E i I iz Herpes simplex virusa tipa 1 koji blokiraju neutralizaciju onkolitskih virusa posredovanu antitijelima čime se povećavaju šanse da onkolitski virusi unište stanice karcinoma in vivo.

Ključne riječi: terapija karcinoma, glikoproteini E i I, Herpes simplex virusa tipa 1, neutralizacija onkolitskih virusa posredovana antitijelima

»Rhoen Klinikum AG« Hospital, 97616 Bad Neustadt ad Saale, Germany 